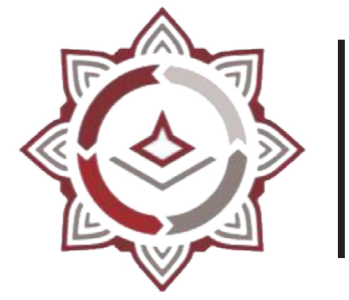

BISNIS: Jurnal Bisnis dan Manajemen Islam

P-ISSN: 2442-3718, E-ISSN: 2477-5533

Volume 9, Nomor 2, Desember 2021 (PP : 335-344)

https://journal.iainkudus.ac.id/index.php/Bisnis/index

http://dx.doi.org/10.21043/bisnis.v9i2.13083

\title{
KEPUTUSAN PENGGUNAAN UANG ELEKTRONIK PADA ERA PANDEMI COVID-19 DI KUDUS
}

\author{
Nurul Izzatun Nisa ${ }^{1}$, Muhamad Mustaqim ${ }^{2}$ \\ Institut Agama islam Negeri kudus ${ }^{1,2}$ \\ izzatunnisa@gmail.com¹muhamadmustaqim@iainkudus.ac.id ${ }^{2}$
}

\begin{abstract}
In the pandemic era the use of electronic money payments has increased quite high. The purpose of the study was to determine the influence of trust and product knowledge on electronic money usage decisions. The research uses quantitative methods with this type of field research. The dissemination of questionnaires was conducted in this study using incidental sampling techniques with a sample number of 100 electronic money users in Kudus Regency. This study obtained the results of the findings, namely first, the significant influence of trust variables on the decision to use electronic money. Second, there is a significant influence of product knowledge variables on the decision to use electronic money.
\end{abstract}

Keywords: Trust, Product Knowledge, Electronic Money Usage Decisions

Abstrak

Di era pandemi penggunaan pembayaran uang elektronik mengalami kenaikan yang cukup tinggi. Tujuan dari penelitian ini adalah untuk mengetahui pengaruh trust dan pengetahuan produk terhadap keputusan penggunaan uang elektronik. Penelitian ini menggunakan metode kuantitatif dengan jenis penelitian lapangan. Penyebaran kuesioner dilakukan pada penelitian ini menggunakan teknik sampling insidental dengan jumlah sampel 100 pengguna uang elektronik di Kabupaten Kudus. Penelitian ini memperoleh hasil temuan, yaitu pertama, adanya pengaruh yang signifikan variabel trust terhadap keputusan penggunaan uang elektronik. Kedua, adanya pengaruh yang signifikan variabel product knowledge terhadap keputusan penggunaan uang elektronik.

Kata Kunci : Trust, Product Knowledge, Keputusan Penggunaan Uang Elektronik 


\section{Latar Belakang}

Munculnya virus Corona pada awal tahun 2020 sudah memengaruhi negaranegara di semua benua, termasuk di negara Indonesia. Covid-19 mulai muncul di Wuhan, ibu kota provinsi Hubei di RRC, pada Desember 2019 lalu menyebar ke seluruh Asia dan dunia. Dampak dari Covid-19 ini sangat berpengaruh pada tatanan kehidupan masyarakat, mulai dari sektor ekonomi, pendidikan, sosial, dan tatanan hidup lainnya.

Pesatnya penyebaran Covid-19 ditakuti oleh semua kalangan dan salah satu yang bisa menjadi media perkenalan virus ini adalah kuman yang menempel pada uang tunai (Krismawintari et al., 2020). Dalam kehidupan ekonomi sebuah negara, uang mempunyai peran yang sangat vital sebab uang mempunyai berbagai fungsi, diantaranya yakni sebagai media penukaran dan media pembayaran serta pengukuran harga oleh karena itu bisa dinyatakan jika uang ialah salah satu alat utama pada perekonomian.

Melalui penggunaan uang, perekonomian sebuah negara bisa berjalan sesuai dengan harapan, oleh karena itu bisa memberikan dukungan dalam mewujudkan tujuan negara, yang mana bisa mewujudkan kemakmuran serta keadilan untuk masyarakat. Di sisi lain, dan sudut pandang aspek moneter, beredarnya sejumlah uang pada sebuah negara harus dilakukan pengelolaan secara bijaksana sesuai dengan keperluan perekonomian. Berkembangnya sebuah teknologi informasi sudah berdampak pada berbagai bidang, termasuk di bidang system pembayaran, terkhusus system pembayaran ritel dengan adanya media pembayaran yang dikenal dengan electronic money (e-money).

Hal ini dapat meminimalkan penggunaan uang kertas dan menjadi salah satu solusi alternatif untuk mengurangi penyebaran kuman saat pandemic virus corona. Banyak hal yang mengalami perubahan sebab adanya pandemi virus Corona, tidak terkecuali dalam bidang ekonomi. Pergeseran perilaku konsumen dan peningkatan penggunaan uang elektronik akan berdampak pada metode pembayaran tradisional, mendorong jalan ke masa depan tanpa uang tunai. Keuntungan dari transaksi ini antara lain kemudahan, penghematan biaya, dan pencatatan elektronik di jasa keuangan.

Siring dengan berkembangnya teknologi di bidang finansial yang dikenal dengan sebutan Finansial Teknologi (financial technology), banyak perusahaan yang mulai menawarkan kemudahan serta kenyamanan penggunaan produk uang 
elektronik kepada para pelanggan atau konsumennya. Di tambah lagi dengan keadaan saat ini, masyarakat dibatasi pergerakannya karena adanya pandemic Covid-19. Sehingga perusahaan memiliki peluang untuk meningkatkan minat masyarakat dalam menggunakan produk yang ditawarkan dengan berbagai kelebihan yang dimiliki oleh produk tersebut.

Di tahun 2014 Bank Indonesia (BI) telah mengajak masyarakat melaksanakan Gerakan Nasional Non Tunai (GNNT). Bahkan sejak tanggal 31 Oktober 2017, pemerintah mewajibkan penggunaan e-money atau uang elektronik sebagai alat untuk pembayaran pada gerbang tol untuk menggantikan uang tunai. Maka pengguna jalan dituntut untuk memakai e-money dalam transaksi yang dilakukan (Kusuma, 2020).

Selama pemberlakuan Pembatasan Sosial Berskala Besar (PSBB) jumlah uang elektronik (e-money) yang digunakan mengalami kenaikan. Pada bulan April 2020, jumlahnya sebanyak 412,1 juta, nilai tersebut meningkat dari bulan sebelumnya yaitu sebesar 330,4 juta. Namun dalam bulan setelahnya kembali mengalami penurunan dan menjadi 346,9 juta pengguna. Kemudian di bulan Juni 2020, penggunaan uang elektronik (e-money) sedikit meningkat sejumlah 353,6 juta penggunaan. Selama pandemic Covid-19, pembayaran dalam bentuk digital telah menolong lebih banyak individu dalam melakukan transaksi. Menurut Asosiasi Fintech Indonesia menyebutkan bahwa perusahaan di bidang teknologi finansial mempunyai potensi dalam mendukung bangkitnya ekonomi nasional (Jayani, 2020).

Penggunaan layanan uang elektronik (e-money) dipengaruhi oleh adanya informasi mengenai instrument uang elektronik (e-money) yang diperoleh. Salah satu faktor yang dapat mempengaruhi yaitu kepercayaan (trust), dimana faktor kepercayaan (trust) menjadi hal pentingdalampenggunaan uang elektronik (e-money) sebagai media transaksi yang digunakan oleh konsumen. Faktor kepercayaan dalam hal ini berarti bahwa bagaimana pihak penyedia layanan fasilitas uang elektronik (e-money) mampu memberikan jaminan keamanan serta kerahasiaan kepada konsumen untuk menjadikan konsumen tersebut percaya.

Selain itu, yang memungkinkan dapat berpengaruh pada penggunaan uang elektronik (e-money) adalah pengetahuan produk (product knowledge). Konsumen memiliki keinginan untuk membeli atau memilih sebuah produk, berdasarkan pada pengalamannya dalam memilih, menggunakan dan mengkomunikasikan sebuah produk. Hal tersebut perlu adanya spesifikasi pada setiap produk uang elektronik yang dikeluarkan perusahaan. Informasi mengenai spesifikasi produk layanan 
uang elektronik (e-money) dapat memberikan pengetahuan pada konsumen yang kemudian digunakan untuk menentukan produk mana yang akan dipilih dan sesuai dengan kebutuhannya.

Artikel ini bermaksud untuk melakukan pengujian secara empiris pengaruh trust dan Product Knowledge terhadap Keputusan Penggunaan Uang Elektronik di Era Pandemi Covid-19 di Kota Kudus. Hasil penelitian memberikan kontribusi pengetahuan mengenai faktor-faktor yang mempengaruhi keputusan membelu menggunakan uang elektronik, khususnya pada masa pandemi.

\section{METODE PENELITIAN}

Penelitian ini merupakan penelitian lapangan (field research), dengan menggunakan pendekatan kuantitatif. Pada penelitian ini, yang menjadi populasi yaitu masyarakat pengguna uang elektronik (e-money) di Kota Kudus. Sedangkan teknik sampling yang digunakan ialah teknik stratified random sampling. Stratified random sampling merupakan sebuah teknik pengambilan sampel yang menaruh perhatian pada suatu tingkatan dalam elemen populasi. Dengan menggunakan metode Slovin, maka didapatkan jumlah sample sebesar 100 penduduk dari total keseluruhan masyarakat Kota Kudus yang memakai uang elektronik (e-money). Kemudian dari total sampel yang telah ditetapkan tersebut dibagi kembali sesuai dengan proporsi kecamatan di Kota Kudus.

\section{HASIL PENELITIAN DAN PEMBAHASAN}

\section{Analisi pengaruh Trust terhadap Keputusan Penggunaan Uang Elektronik di Era Pandemi Covid-19 di Kabupaten Kudus}

Variabel Trust mempunyai pengaruh terhadap Keputusan Penggunaan uang elektronik di era pandemi Covid-19 di Kabupaten Kudus, yang bersumber atas perolehan data penelitian yang kemudian diolah peneliti menggunakan software SPSS 23.0 didaapat bahwa nilai $\mathrm{T}$ hitung 2,763 $>\mathrm{T}$ tabel 1,98472. Maka nilai $\mathrm{T}_{\text {hitung }}$ terdapat di wilayah $\mathrm{H}_{\mathrm{o}}$ ditolak, dan $\mathrm{H}_{\mathrm{a}}$ diterima dengan taraf signifikan > 0,05 yaitu 0,007. Berdasarkan nilai uji T parsial, Trust $\left(\mathrm{X}_{1}\right)$ adalah variabel independent yang memberi pengaruh secara signifikan terhadap keputusan penggunaan. Dan $\mathrm{T}_{\text {hitung }}$ bernilai positif yang bermakna bahwa Trust memiliki pengaruh positif trehadap keputusan penggunaan uang elektronik (e-money) di Kabupaten Kudus. Sedangkan variabel trust dalam persamaan regresi memiliki nilai sebesar 0,361 . Jika variabel 
trust dinaikkan sebesar $100 \%$ maka nilai keputusan penggunaan akan meningkat sebanyak $36,1 \%$.

Berdasarkan hasil jawaban responden diketahui bahwa item (X1.3) memiliki pengaruh terbesar yaitu pelayanan jasa uang elektronik sebesar 62\%. Maka, dapat disimpulkan bahwa konsumen menggunakan uang elektronik karena pelayanan yang di dapat sesuai dengan harapan konsumen, sehingga muncul kepercayaan konsumen terhadap suatu produk. Kepercayaan sangat penting dalam sebuah komitmen atau janji, selain itu kepercayaan juga dapat muncul apabila konsumen mempercayai bahwa penerbit jasa uang elektronik (e-money) dapat dipercayai serta memiliki tingkat integritas yang tinggi.

Trust melibatkan sikap kesediaan dari seseorang untuk melakukan suatu hal karena adanya keyakinan jika orang tersebut dapat memberikan kepuasan sesuai harapan yang diinginkan (Permata S, \& Kerti, 2020). Adanya kepercayaan yang dapat diberikan kepada konsumen akan berdampak dalam jangka panjang.

Untuk membentuk konsumen yang memiliki loyaltas terhadap perusahaan, maka perusahaan perlu menjalin kepercayaan yang baik kepada para konsumennya dalam jangka panjang. Kepercayaan ini harus dapat dibuktikan serta perlu dibangun sejak awal dari adanya hubungan dengan konsumen ataupun rekan bisnis lainnya. Pada saat pelanggan percaya terhadap perusahaan, maka mereka akan lebih tertarik untuk terus melakukan pembelian di perusahaan yang bersangkutan. Kepercayaan merupakan aspek yang penting dalam suatu perjanjian, dan komitmen mampu terealisasikan bila sewaktu-waktu berarti (Suprapto \& Wahyuddin, 2020).

Peneliti berpendapat, trust yaitu hal utama yang mendasari sebuah relasi antar sesama. Di era pandemic Covid-19 adanya kepercayaan yang dapat dijadikan jaminan dalam penggunaan uang elektronik, yang mana mampu memberikan rasa aman terhadap diri konsumen. Keamanan tersebut dapat berupa identitas konsumen, nomor-nomor tertentu, alamat dan sebagainya yang harus dirahasiakan oleh pihak penerbit jasa uang elektronik. Sebagai bentuk perlindungan terhadap konsumen, sehingga sistem teknologi yang digunakan dapat memberi kepercayaan terhadap konsumen atau pengguna uang elektronik.

Peneliti memperoleh hasil yang sejalan dengan penelitian terdahulu yang telah telah dilakakun oleh Dwi Yunita Indah "Analisis Keputusan Nasabah Menggunakan Transaksi Non Tunai di Era Pandemi Covid-19" yang di dalamnya menjelaskan kepercayaan mempunyai pengaruh positif dan signifikan terhadap keputusan 
nasabah dalam memakai transaksi non tunai. Kepercayaan menurut Chauhan adalah teknologi yang diharapkan konsumen mampu memberikan nilai manfaat serta dipercaya untuk menyelasikan tugas dengan sebaik mungkin. Keprcayaan akan memicu calon konsumen untuk memutuskan menggunakan pembayaran non tunai jika menurut ia jasa yang ditawarkan dapat memberi kepercayaan (Indah et al., 2020).

\section{Analisi pengaruh Product Knowledge terhadap Keputusan Penggunaan Uang Elektronik di Era Pandemi Covid-19 di Kabupaten Kudus}

Berdasarkan data penelitian, variabel product knowledge memiliki pengaruh terhadap keputusan penggunaan dengan hasil nilai signifikan yaitu 0,000 $<0,05$. Selain itu nilai $\mathrm{t}_{\text {hitung }} 6,412$ lebih besar dari $\mathrm{t}_{\text {tabel }}$ 1,98472. Sedangkan hasil persamaan untuk variabel product knowledge mempunyai nilai sebesar 0,650. Jika variabel product knowledge dinaikkan sebesar $100 \%$ maka keputusan penggunaan akan meningkat sebesar $65 \%$.

Peneliti menemukan bahwa, sebagian besar calon pengguna telah memiliki pengetahuan mengenai produk yang ada. Hal tersebut dapat dilihat dari jumlah responden sebanyak $62 \%$ pada pernyataan item (X2.3), bahwa responden dapat mengidentifikasi nama/simbol tertentu yang digunakan dalam uang elektronik. Variabel product knowledge menggunakan 4 indikator yaitu kesadaran terhadap kategori produk dan merek produk; terminology produk; atribut atau ciri produk; kepercayaan mengenai kategori produk secara umum dan mengenai merek secara spesifik; yang dijelaskan menjadi 9 (sembilan) item pernyataan (Yuniarti, 2015). Kemudian, jawaban responden yang diperoleh telah mewakili variabel pengetahuan produk (product knowledge) yang menggambarkan hubungan pengetahuan produk dengan keputusan penggunaan.

Pengetahuan produk penting bagi pemasar dalam menginformasikan serta menawarkan produk/jasa kepada konsumen. Dengan upaya promosi serta sosialisasi kepada konsumen khususnya segi keistimewaan produknya dibandingkan produk lain (pesaing). Konsumen yang memiliki pengetahuan rendah mengenai produk akan cenderung melihat petunjuk ekstrinsiknya saja, misalnya dengan melihat harga atau merek sebagai acuan dalam mengevaluasi sebuah produk.

Peneliti dapatmenyimpulkan bahwa penelitian memperoleh datayaitu variabel Product Knowledge $\left(\mathrm{X}_{2}\right)$ memiliki pengaruh positif dan signifikan terhadap variabel 
keputusan penggunaan (Y) uang elektronik (e-money) di era pandemic Covid-19 di Kabupaten Kudus. Pelanggan yang tidak mempunyai wawasan mengenai produk, ia dapat salah dalam mengambil keputusan. Akibatnya, kebutuhan dari konsumen tersebut tidak dapat dipenuhi secara maksimal.

Menurut peneliti, pengetahuan produk adalah berbagai wawasan tantang sebuah produk atau jasa baik yang dimiliki oleh konsumen maupun calon konsumen. Informasi tersebut akan digunakan individu dalam melakukan pemanfaatan produk uang elektronik (e-money). Informasi mengenai sebuah produk ataupun jasa sangat penting untuk diketahui oleh calon konsumen, sebab pemilihan produk/ jasa yang tidak sesuai dengan kebutuhan akan menimbulkan persepsi buruk dari konsumen terhadap produk. Padahal letak kesalahan berasal dari pihak konsumen yang tidak memperhatikan fungsi atau kegunaan dari produk/jasa. Sehingga konsumen merasa tidak puas, karena rendahnya pengetahuan pada diri konsumen. Pengetahuan produk memiliki pengaruh yang signifikan, maka semakin tinggi pengetahuan konsumen mengenai produk uang elektronik maka akan semakin banyak kesempatan dalam menggunakannya. Di era pandemi Covid-19 penting bagi konsumen untuk mengetahui jenis dan kategori kebutuhan yang harus dipenuhi dan uang elektronik (e-money) dapat menjadi solusi atas metode pembayaran pada saat melakukan pemenuhan kebutuhan tersebut tanpa khawatir akan tertular virus Covid-19.

\section{Analisis pengaruh Trust dan Product Knowledge terhadap Keputusan Penggunaan Uang Elektronik di Era Pandemi Covid-19 di Kabupaten Kudus}

Pada variabel trust dan product knowledge diketahui dari hasil pengujian secara statistik menggunakan software SPSS 23.0 dalam uji F simultan menyatakan terdapat pengaruh antara trust $\left(\mathrm{X}_{1}\right)$ dan product knowledge $\left(\mathrm{X}_{2}\right)$ secara bersama dan signifikan atas keputusan penggunaan uang elektronik di era pandemic Covid-19 di Kabupaten Kudus. Dalam uji tersebut didapat F hitung yang lebih besar dari nilai F tabel, yaitu 49,712 > 3,09. Sedangkan, taraf signifikan dalam uji F pada variabel trust $\left(\mathrm{X}_{1}\right)$ dan product knowledge $\left(\mathrm{X}_{2}\right)>0,05$ yaitu sebesar 0,000 secara simultan/ bersama-sama memiliki pengaruh. Maka variabel trust dan product knowledge terdapat pengaruh signifikan terhadap keputusan penggunaan uang elektronik (e-money) di era pandemic Covid-19 di Kabupaten Kudus. 
Sedangkan hasil persamaan regresi, apabila keputusan penggunaan tidak dipengaruhi trust dan product knowledge maka tingkat keputusan penggunaan uang elektronik sebesar 3,347. Hasil persamaan diketahui nilai variabel trust dan product knowledge adalah sebesar $36,1 \%$ dan $65 \%$ yang mana variabel product knowledge bernilai lebih besar dari variabel trust. Pengaruh yang diberikan oleh variabel trust hanya sebanyak 36,1\%, menurut penulis hal tersebut disebabkan karena sebuah kepercayaan terhadap uang elektronik (e-money) dapat terjadi namun belum tentu akan diikuti dengan tahap keputusan penggunaan. Karena yang ditimbulkan dari variabel kepercayaan berupa persepsi dari masing-masing individu terhadap sebuah produk. Sesuai dengan pendapat Mowen dan Minor mengenai 3 (tiga) jenis kepercayaan yang dibentuk seseorang, diantaranya (Sangadji \& Sopiah, 2013) :

1) Kepercayaan objek-atribut, konsumen memberi pernyataan mengenai apa yang mereka ketahui tentang suatu hal.

2) Kepercayaan atribut-manfaat, persepsi konsumen atau pelanggan mengenai seberapa jauh sebuah atribut tertentu dapat menghasilkan serta memberi manfaat tertentu.

3) Kepercayaan objek-manfaat, persepsi konsumen mengenai seberapa jauh produk, orang atau jasa khusus yang dapat memberikan manfaat tertentu.

Sedangkan pengaruh yang diberikan variabel product knowledge terhadap keputusan penggunaan memiliki nilai sebesar 65\%. Keputusan penggunaan di awali dengan adanya permasalahan atau kebutuhan dalam diri konsumen (Kotler \& Keller, 2009). Melalui tuntutan kebutuhan tersebut kemudian konsumen akan mencari informasi mengenai uang elektronik (e-money) sebagai bahan pertimbangan sebelum mengambil keputusan. Adanya pengetahuan mengenai produk dapat membantu seseorang dalam mengidentifikasi kebutuhan yang diperlukan. Sehingga seseorang tersebut menemukan solusi atas kebutuhan tersebut. Melalui penyedia jasa uang elektronik (e-money) yang telah menyediakan berbagai jenis transaksi. Dalam uang elektronik (e-money) pengetahuan mengenai jenis-jenis transaksi yang dapat dipilih oleh individu, yaitu :

1) Penerbitan dan pengisian ulang uang elektronik (e-money)

2) Transaksi pembayaran melalui uang elektronik (e-money)

3) Transfer

4) Tarik tunai

5) Refound atau redeem, penukaran kembali nilai uang elektronik kepada penerbit. 
Berdasarkan hasil jawaban pernyataan penelitian, sebanyak $66 \%$ responden yang menyatakan setuju dengan item pernyataan (Y1.1) bahwa responden menggunakan uang elektronik (e-money) dalam transaksi pembayaran karena alasan jarak antar lokasi yang jauh. Hal ini sesuai dengan teori bahwa jarak termasuk faktor yang mempengaruhi keputusan penggunaan, yangmana terbagi dalam 3 jenis, yaitu faktor pribadi, faktor psikologi, dan faktor sosial. Sedangkan faktor pribadi ini selanjutnya dibedakan lagi ke dalam tiga kategori berupa faktor demografi, situasional, dan tingkat keterlibatan (Sangadji \& Sopiah, 2013). Alasan responden dalam penggunaan uang elektronik adalah jarak yangmana termasuk dalam faktor pribadi (situasional) dan diartikan sebagai suatu konsidi yang berasal dari luar diri konsumen tersebut.

Keputusan penggunaan uang elektronik (e-money) secara signifikan dapat dipengaruhi oleh adanya Trust dan Product Knowledge. Apabila kepercayaan yang dimiliki oleh konsumen tinggi dan pengetahuan konsumen yang luas tentang produk, maka tingkat penggunaan uang elektronik (e-money) juga akan semakin tinggi. Konsumen dalam hal ini memiliki masalah yang berasal dari luar diri konsumen berupa jarak, namun dengan adanya pengetahuan mengenai fitur dari produk uang elektronik dapat dijadikan sebagai solusi dalam pemecahan masalah tersebut. Melalui uang elektronik ini konsumen dapat mengambil manfaat dengan cara melakukan transfer dana kepada pihak yang menjadi tujuannya. Dengan mempercayakan salah satu produk uang elektronik yang diterbitkan oleh penyedia jasa e-money sebagai media dalam bertransaksi. Kepercayaan yang saling ditimbulkan antara penyedia jasa dengan pengguna atau konsumen uang elektronik dapat meningkatkan keputusan penggunaan uang elektronik di era Pandemi Covid-19.

\section{SIMPULAN}

Kepercayaan atau trust memiliki pengaruh signifikan dan positif terhadap keputusan penggunaan uang elektronik di era pandemi Covid-19 di Kabupaten Kudus, demikian juga dengan pengetahuan produk, memiliki pengaruh positif signifikan terhadap keputusan penggunaan uang elektronik. Secara simultan, kedua variabel tersebut juga menunjukkan pengaruh yang positif terhadap keputusan penggunaan uang elektronik di era pandemi Covid-19 di Kabupaten Kudus. 


\section{DAFTAR PUSTAKA}

Indah, D. Y., Setiawati, I., \& Indiworo, Rr. H. E. (2020). Analisis Keputusan Nasabah Menggunakan Transaksi Non Tunai di Era Pandemi Covid 19. 16(2).

Jayani, D. H. (2020). Transaksi E-money Meningkat Saat PSBB. https://databoks. katadata.co.id/datapublish/2020/09/11/transaksi-e-money-meningkatsaat-psbb

Kotler, P., \& Keller, K. L. (2009). Manajemen Pemasaran, Edisi 13, Jilid 1. Airlangga.

Krismawintari, N. P. D., Komalasari, Y., Utama, I. G. B. R., Trimurti, C. P., \& Junaedi, I. W. R. (2020). Decision Model of Use E-Money in Covid-19 Pandemic Situation. Technium Social Sciences Journal, 10, 280-290. https://doi.org/10.47577/tssj. v10i1.1333

Kusuma, Nuruni Ika. (2020). Analisis Tingkat Persepsi Konsumen Pada Minat Penggunaan Kartu E-Money / Procuratio: Jurnal Ilmiah Manajemen. 8(2). http://www.ejournal.pelitaindonesia.ac.id/ojs32/index.php/PROCURATIO/ article/view/653

Permata S, A. R., \& Kerti, N. N. (2020). Kepercayaan Pelanggan Di Antara Hubungan Citra Perusahaan Dan Kewajaran Harga Dengan Loyalitas Pelanggan Mapemall. com. Lakeisha.

Sangadji, E. M., \& Sopiah. (2013). Perilaku Konsumen, Pendekatan Praktis. Penderbit ANDI.

Suprapto, R., \& Wahyuddin, Z. (2020). Buku Ajar Manajemen Pemasaran. Myria Publisher.

Yuniarti, V. S. (2015). Perilaku Konsumen Teori dan Praktik. CV Pustaka Setia. 